\title{
Manfaat Bekatul Beras Putih dan Angkak dalam Pembuatan Cookies dan Roti
}

\author{
Claudia Coritama, Franciscus Sinung Pranata*, Yuliana Reni Swasti \\ Fakultas Teknobiologi, Universitas Atma Jaya Yogyakarta, Indonesia \\ *Corresponding author: sinung.pranata@uajy.ac.id
}

\begin{abstract}
Background: Adding ingredients to a food product has been done by researchers to increase the quality of the product. This review was written by analyzing various researches sources based on defined criteria and aims to analyze the potentials of rice bran and angkak to increase the quality of cookies and bread. Rice bran is a secondary product obtained from rice milling, which nowadays has been researched and utilized to enhance the nutritional values of various food products. Angkak is a rice fermentation product by Monascus purpureus, which often used as natural food colorant and herbal medicine. Result: Previous research has shown that rice bran can increase levels of fiber and antioxidants for bakery products, meanwhile angkak has the ability to lower cholesterol levels in blood and contains color pigments that can affect the physical appearance of cookies and bread. Those potentials are also followed by concerns regarding safety issues of angkak. Conclusion: Rice bran and angkak can be added to cookies and bread to increase it's physical and chemical properties. Angkak can be added to food products without giving any side effects if added in normal dosage, and can be heated to detoxificate the citrinin contained.
\end{abstract}

Keywords: angkak, rice bran, cookies, bread

\begin{abstract}
ABSTRAK
Latar belakang: Penambahan bahan pada suatu produk pangan seringkali dilakukan untuk meningkatkan kualitas produk tersebut. Ringkasan ini dibuat dengan analisa berbagai sumber penelitian yang telah ada berdasarkan kriteria yang ditetapkan, dan bertujuan untuk mengkaji potensi bekatul beras putih dan angkak untuk meningkatkan kualitas cookies dan roti. Bekatul beras putih merupakan produk samping penggilingan beras yang saat ini banyak diteliti dan dimanfaatkan untuk meningkatkan nilai gizi suatu produk makanan. Angkak merupakan hasil fermentasi beras oleh kapang Monascus purpureus yang selama ini banyak dimanfaatkan sebagai pewarna makanan alami dan obat herbal. Hasil: Penelitian telah membuktikan bahwa bekatul beras putih dapat meningkatkan kadar serat dan antioksidan pada produk bakery, sementara angkak memiliki kemampuan menurunkan kolesterol dan memiliki pigmen warna yang dapat mempengaruhi penampilan cookies dan roti. Potensi tersebut diikuti dengan kekhawatiran yang muncul mengenai isu keamanan pangan pada angkak. Kesimpulan: Bekatul beras putih dan angkak dapat ditambahkan dalam pembuatan cookies dan roti untuk memberikan peningkatan pada parameter fisik dan kimia. Angkak dapat ditambahkan pada produk pangan tanpa diikuti efek samping apabila ditambahkan pada dosis yang normal, serta dapat dilakukan upaya pemanasan untuk mendetoksifikasi citrinin.
\end{abstract}

Kata kunci: angkak, bekatul beras putih, cookies, roti 


\section{PENDAHULUAN}

Bekatul beras putih merupakan hasil samping dari proses penggilingan padi. Di Indonesia, bekatul dihasilkan sebanyak 4-6 juta ton per tahun, yang secara umum banyak digunakan sebagai pakan ternak (1). Bekatul beras putih memiliki zat gizi yang tinggi dan beragam (2). Oleh karena itu, telah banyak dilakukan penelitian yang menggunakan bekatul beras putih sebagai bahan pengganti atau tambahan pada produk pangan (3).

Bekatul beras putih merupakan produk yang telah digunakan dalam produk bakery dan terbukti dapat meningkatkan penilaian cookies dan roti, baik berdasarkan kadar zat gizi ataupun penilaian fisik (4), sementara angkak memiliki potensi yang baik untuk kesehatan dan properti pigmen yang dapat digunakan sebagai pewarna (5). Apabila diterapkan secara praktis, penambahan bekatul beras putih dan angkak diharapkan dapat memberi peningkatan pada kadar serat, kadar antioksidan, dan penilaian sensori pada cookies dan roti (6). Selain bekatul beras putih, bahan lain juga dapat ditambahkan pada produk cookies atau roti untuk meningkatkan penilaian pada parameter lain, misalnya penambahan angkak sebagai pewarna.

Angkak adalah produk fermentasi beras oleh kapang Monascus purpureus. Angkak telah banyak dikonsumsi terutama di daerah Asia dan banyak dikenal sebagai obat. Sejumlah penelitian telah membuktikan angkak memiliki kemampuan untuk menurunkan kadar kolesterol (7). Angkak dikenal dengan kandungan pigmen yang memberikan warna merah, dan telah banyak digunakan sebagai pewarna makanan (8), sehingga penggunaannya pada cookies dan roti memiliki potensi. Literature review ini bertujuan untuk menganalisis potensi bekatul beras putih dan angkak sebagai bahan tambahan pada cookies.

Penambahan dan kombinasi bahanbahan pembuat cookies dan roti telah banyak dilakukan untuk meningkatkan kualitas fisik maupun kimianya (9). Salah satu komponen yang banyak dikembangkan dalam produk cookies dan roti adalah serat pangan. Makanan yang banyak dikonsumsi di masa modern ini cenderung tinggi akan karbohidrat dan lemak, sehingga pemenuhan serat seringkali tidak tercukupi, sehingga penambahan bahan yang tinggi serat dapat dilakukan untuk mengatasi permasalahan tersebut (10). Serat memiliki sejumlah manfaat bagi kesehatan, diantaranya: melancarkan pencernaan, mengurangi kadar kolesterol dalam darah, menurunkan tekanan darah, memperlama rasa kenyang, dan mencegah kanker usus (11).

Proses pemanggangan yang dilalui oleh produk cookies dan roti dapat memberikan pengaruh bagi kualitas fisik maupun kimianya. Kandungan protein dan karbohidrat pada bahan-bahan cookies dan roti dapat memicu reaksi Maillard, yang menyebabkan perubahan warna menjadi kecoklatan. Suhu tinggi juga dapat mempengaruhi kadar zat gizi pada cookies dan roti, terutama pada senyawa yang bersifat termolabil, misalnya tokoferol (4).

Tinjauan literatur dilakukan berdasarkan penelitian yang telah dilakukan sebelumnya. Referensi dan sumber yang diacu didapatkan melalui internet, dengan kata kunci yang berkaitan dengan naskah: bekatul beras putih, angkak, roti, cookies, antioksidan, dsb. Jurnal berbahasa Indonesia yang diacu memiliki indeks SINTA S1-S4, sementara jurnal internasional yang diacu memiliki reputasi Q1-Q4. 


\section{TINJAUAN LITERATUR}

\section{Zat Gizi pada Bekatul Beras Putih}

Dalam produksi beras, gabah akan disosoh menjadi beras utuh atau beras pecah kulit (whole rice/brown rice), yang kemudian disosoh kembali, menghasilkan beras, dedak, dan bekatul (12). Bekatul beras terdiri dari lapisan perikarpus, lapisan biji, nuselus, dan lapisan aleuron, yang menyusun $7 \%$ dari berat gabah (13). Secara kimia, bekatul beras putih tersusun oleh 4$8 \%$ mineral (besi, fosfor, dan magnesium), $11-13 \%$ protein, $11,5 \%$ serat, dan $20 \%$ dalam bentuk minyak (3).

Berdasarkan komposisi gizinya, bekatul beras putih memiliki keunggulan daripada tepung gandum (Tabel 1). Keunggulan pada kadar protein, mineral, dan serat pangan menunjukkan bahwa bekatul beras putih memiliki potensi untuk menggantikan tepung gandum, dan cocok dikonsumsi oleh orang yang sedang ingin mengurangi konsumsi karbohidrat. Akan tetapi, kandungan lemak yang lebih tinggi pada bekatul beras putih merupakan sebuah hambatan bagi pengolahannya karena dapat menyebabkan ketengikan, sehingga tidak dapat disimpan dalam waktu lama (12).

Keunggulan zat gizi pada bekatul beras putih dapat memberikan berbagai manfaat bagi kesehatan. Serat diketahui mampu mencegah penyakit jantung koroner, stroke, hipertensi, diabetes, obesitas, dan gangguan pencernaan (14). Antioksidan yang terkandung dalam bekatul maupun minyak bekatul mampu memberikan efek hipolipidemik, peningkatan pertumbuhan, stimulasi hipotalamus, antioksidan, penurunan kadar kolesterol darah, pencegah pertumbuhan tumor, anti-diabetes, dan regulasi glukosa dalam darah (3).

Bekatul beras putih memiliki keunggulan kadar gizi apabila dibandingkan dengan tepung gandum, yaitu pada kadar protein, lemak, abu, dan serat pangan yang lebih tinggi, sementara kadar karbohidratnya lebih rendah. Bekatul beras putih mengandung berbagai jenis asam amino, diantaranya lisin, histidin, arginin, asam aspartat, thronin, serin, asam glutamat, prolin, glisin, alanin, sistin, valin, metionin, isoleusin, leusin, tirosin, dan fenilalanin, dengan asam glutamat sebagai protein yang paling dominan (12,5-22,58 $\mathrm{g} / \mathrm{kg}$ ) (15). Bekatul beras putih mengandung berbagai macam vitamin dan mineral, dengan vitamin yang dominan adalah niasin dan mineral yang dominan adalah fosfor (16) (Tabel 2).

Serat yang terdapat dalam bekatul beras putih yaitu selulosa, hemiselulosa, arabinosilan, lignin, pektin, dan $\beta$-glucan (17). Jenis serat yang dominan pada bekatul beras putih adalah hemiselulosa dan selulosa, yaitu kandungan hemiselulosa sebanyak 9,6-12,8 \% dan selulosa sebanyak 8,7-11,4 \% (18). Bekatul beras putih juga mengandung senyawa antioksidan yang larut dengan minyak, yaitu $\alpha$-tokoferol $(35,9 \%)$ dan $\gamma$-orizanol $(62,9 \%)$, serta terdapat asam fenolik $(1,2 \%)$ yang hampir seluruhnya berada dalam bentuk bebas (19). Zat gizi pada bekatul beras putih dipengaruhi oleh varietas padi, terutama terdapat perbedaan pada kadar antioksidan dan serat tak larut (20).

Asam lemak yang terkandung dalam bekatul beras putih adalah asam palmitat (21-26\%), asam linoleat (31-33\%), dan asam oleat $(37-42 \%)$ (21). Asam lemak yang terkandung dalam bekatul beras putih bersifat tidak dapat tersaponifikasi, yang juga memberikan sifat hipolipidemik atau dapat menurunkan kadar kolesterol dalam darah (22). Pengolahan bekatul beras putih menjadi minyak bekatul juga bebas dari lemak trans (23). 
Tabel 1. Komposisi Gizi Tepung Gandum dan Bekatul Beras Putih (\% kering)

\begin{tabular}{lcc}
\hline & $\begin{array}{c}\text { Tepung } \\
\text { Gandum }\end{array}$ & $\begin{array}{c}\text { Bekatul Beras } \\
\text { Putih }\end{array}$ \\
\hline Protein & 12,96 & 15,83 \\
Lemak & 1,79 & 15,84 \\
Abu & 0,61 & 7,72 \\
Serat Pangan & 1,35 & 22,43 \\
Karbohidrat & 84,64 & 60,63 \\
\hline Sumber: Irakli dkk., 2015 (4). &
\end{tabular}

Tabel 2. Komposisi Vitamin dan Mineral pada Bekatul Beras Putih

\begin{tabular}{ll}
\hline Vitamin & Kadar $(\mathrm{mg} / 100 \mathrm{~g})$ \\
\hline Tiamin & $2,50-3,10$ \\
Riboflavin & $0,27-0,32$ \\
Piridoksin & $3,4-4.3$ \\
Niasin & $34-41$ \\
\hline Mineral & Kadar $(\mathrm{mg} / 100 \mathrm{~g})$ \\
\hline Kalsium & $47-54$ \\
Besi & $5,3-5,9$ \\
Magnesium & $683-884$ \\
Sodium & $24-28$ \\
Potasium & $1030-1160$ \\
Fosfor & $668-1390$ \\
Sumber: Rosniyana dkk., 2007 (16).
\end{tabular}

Selain mengandung zat gizi, juga terdapat zat anti-gizi pada bekatul beras putih, yaitu: hemagglutinin-lektin, fitat, dan inhibitor tripsin dalam bentuk protein (3). Selain itu, pada bekatul beras putih juga terkandung oksalat, tanin, dan saponin, yang juga berperan sebagai anti-gizi (24). Zat anti-gizi pada bekatul beras putih bersifat labil pada suhu tinggi, sehingga dapat berkurang kadarnya apabila melalui proses stabilisasi yang melibatkan suhu tinggi tanpa merubah komposisi kimia secara keseluruhan (25).

Bekatul beras putih juga dapat diolah menjadi minyak bekatul, yang diperoleh dengan cara ekstraksi dan menghasilkan produk samping berupa bekatul defatted. Hasil ekstraksi bekatul beras putih mengandung senyawa fitokimia yang tinggi dan berpotensi sebagai antioksidan, yaitu: $\alpha, \beta, \gamma, \delta$-tokoferol, tokotrienol (vitamin E) dan $\gamma$-orizanol, (3). Senyawa orizanol pada bekatul beras putih merupakan senyawa utama yang berperan dalam efek penurunan kadar kolesterol (26). $\gamma$-orizanol menghasilkan asam ferulat, yang kemudian bekerja sebagai pendonor 1 atom hidrogen pada gugus hidroksi fenolik (27).

Pada produk bakery yang pengolahannya melalui perlakuan suhu panas, terdapat kekhawatiran terhadap penyusutan kadar antioksidan, Tokoferol memiliki sifat termolabil dan kadarnya dapat menyusut pada stabilisasi bekatul beras putih yang melibatkan suhu tinggi (28). Penurunan kadar tokoferol dapat disebabkan karena inaktivasi enzim lipoksigenase ketika proses stabilisasi dan berkaitan dengan stres oksidatif pada saat proses pengadonan, yang dapat diatasi dengan waktu pengadonan yang lebih singkat dan penambahan waktu fermentasi, yang bertujuan untuk mengurangi kemampuan adonan dalam mengikat oksigen (4).

Proses pemanggangan pada cookies dengan penambahan water chestnut memberikan kadar antioksidan yang lebih stabil, serta terjadi peningkatan aktivitas penangkapan radikal bebas pada uji DPPH (29). Kenaikan aktivitas antioksidan dapat disebabkan oleh reaksi Maillard pada proses pemanggangan. Reaksi Maillard merupakan reaksi pencoklatan nonenzimatik sebagai reaksi antara gula pereduksi dengan asam amino, dan menghasilkan produk berupa gabungan senyawa yang terdiri dari: aldehid, keton, dikarbonil, akril amida, amina heterosiklik, dan melanoidin (30).

Produk reaksi Maillard memiliki kemampuan antioksidan. Produk reaksi Maillard mampu mengurangi ketersediaan oksigen, dan berperan sebagai katalis 
logam yang kemudian akan menurunkan oksidasi lemak (31). Selain itu, produk reaksi Maillard juga memiliki kemampuan mengkelat logam (32). Atom nitrogen pada melanoidin mampu mengikat ion $\mathrm{Cu}^{2+}$, serta aldehid dan keton dapat berperan sebagai kelompok donor pengkelat pada melanoidin (30).

Suhu pemanggangan yang lebih tinggi dapat menyebabkan peningkatan pada kadar total fenolik dan kapasitas antioksidan, namun terjadi penurunan pada kadar flavonoid dan antosianin. Hal tersebut dapat diatasi dengan penambahan asam sitrat pada adonan cookies, yang dapat membantu stabilisasi antosianin sekaligus meningkatkan kadar senyawa fenolik, asam ferulat, dan p-kumarat, dengan mekanisme penurunan $\mathrm{pH}$ dan asilasi pada residu gula atau kation flavilium (9). Kadar dan aktivitas antioksidan pada produk yang diolah dengan suhu tinggi juga dipengaruhi oleh jenis senyawa dalam bahan. Pada senyawa polifenol, profil fenolik pada masing - masing senyawa memiliki kestabilan yang berbeda pada kondisi termal, serta pada senyawa flavonoid terdapat tingkat aktivitas yang berbeda pada suhu tinggi $\left(140,160\right.$, dan $\left.180^{\circ} \mathrm{C}\right)(29)$.

\section{Stabilisasi Bekatul Beras Putih}

Bekatul beras putih memiliki potensi untuk digunakan dalam pembuatan berbagai produk pangan, namun terdapat hambatan berupa kandungan lemaknya yang dapat memicu ketengikan, sehingga bekatul beras putih memiliki masa simpan yang pendek, dan apabila sudah tengik maka tidak cocok untuk dikonsumsi. Ketengikan tersebut disebabkan oleh hidrolisasi lemak oleh lipase menjadi asam lemak bebas dan gliserol (33). Permasalahan sifat bekatul yang mudah tengik dapat diatasi dengan proses stabilisasi, yaitu proses inaktivasi kerja enzim lipase sehingga tidak terbentuk asam lemak bebas (12). Enzim lipase pada bekatul beras putih dapat bekerja optimum pada kondisi pH 7,5-8 dan suhu $37^{\circ} \mathrm{C}$ (34). Bekatul beras cocok untuk dikonsumsi apabila mengandung asam lemak bebas di bawah $5 \%$ (35).

Stabilisasi bekatul beras putih dengan metode pemanasan microwave telah dianggap sebagai metode yang efektif digunakan untuk memperpanjang masa simpan bekatul beras putih (31). Pemanasan bekatul beras putih dengan microwave pada daya 4-6 W/g selama 3-5 menit berhasil mempertahankan kadar asam lemak bebas di bawah $5 \%$ hingga hari ke 28 (35). Pada penelitian lain, pemanasan dengan microwave selama 4 menit dapat menjaga kadar asam lemak bebas di bawah $5 \%$ selama 24 minggu.

Selain dengan microwave, teknik pemanasan lain pada kondisi tertentu juga dapat dilakukan untuk menjaga kadar asam lemak bebas di bawah $5 \%$ hingga 24 minggu, yaitu metode freeze drying pada suhu $80{ }^{\circ} \mathrm{C}$, pemanasan kering pada suhu $100{ }^{\circ} \mathrm{C}$, serta pemanasan dengan autoclave dan uap etanol selama 20 menit (36). Pemanasan ohmic juga dapat dilakukan untuk menurunkan aktivitas enzim lipase dan mempertahankan kadar asam lemak bebas di bawah $5 \%$ hingga 21 hari, serta cenderung meningkatkan kadar total fenolik, tokoferol, dan orizanol pada perlakuan kadar air 30-40 \% dn kekuatan medan listrik sebesar 75-24 V/cm (37). Pada stabilisasi bekatul beras dengan prinsip pemanasan, terjadi kecenderungan peningkatan kadar senyawa tokol pada suhu kisaran $100{ }^{\circ} \mathrm{C}$, dan menurun pada suhu di atas $120^{\circ} \mathrm{C}(36)$.

Selain dapat menurunkan aktivitas enzim lipase dan kadar asam lemak bebas, proses stabilisasi juga dapat menurunkan 
kadar zat anti-gizi pada bekatul beras putih. Pemanasan dengan metode infrared, pemanasan kering, dan microwave dapat menurunkan kadar fitat, oksalat, saponin, dan inhibitor tripsin (24).

\section{Zat Gizi pada Angkak}

Angkak atau red yeast rice (RYR) merupakan bahan nutrasetikal yang terbuat dari beras putih dan Monascus purpureus atau kapang lain yang masih terkait, dan telah digunakan sebagai perasa, pewarna, dan pengawet pada obat-obatan Cina (38). Angkak mengandung senyawa poliketida, asam lemak tidak jenuh, polisterol, pigmen, dan monakolin $\mathrm{K}$ (lovastatin), dimana lovastatin merupakan senyawa yang berperan utama dalam mekanisme penurunan kadar kolesterol (39). Pigmen yang terkandung dalam angkak merupakan pigmen azaphilone, yang terdiri dari: ankaflavin dan monascin (pigmen berwarna kuning), rubropuktatin dan monaskorubin (pigmen berwarna oranye), serta rubropuktamin dan monaskorubramin (pigmen berwarna coklat) (Gambar 1) (8). Pigmen angkak bersama dengan lovastatin dihasilkan sebagai metabolit sekunder, yang secara umum dikategorikan sebagai karotenoid dan poliketida dan tersusun dari 4 hingga 8 struktur $\mathrm{C}_{2}$, membentuk rantai poliketida (40).
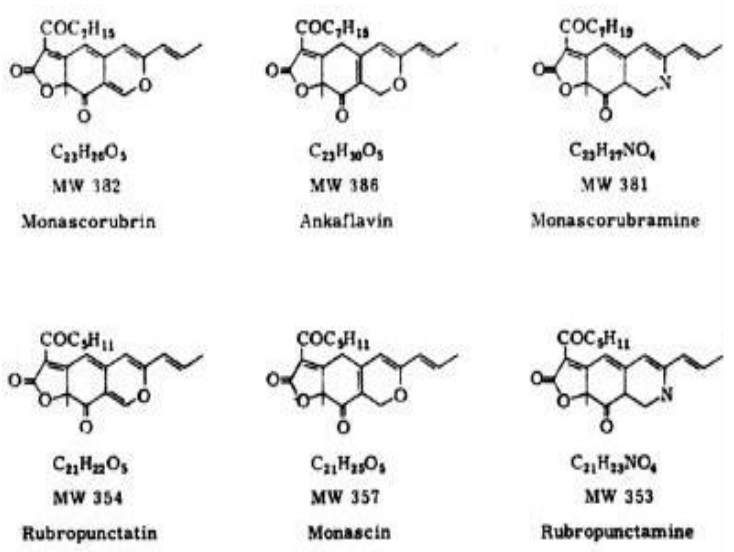

Gambar 1. Struktur Pigmen dalam Angkak (Sumber: Timotius, 2004) (8).

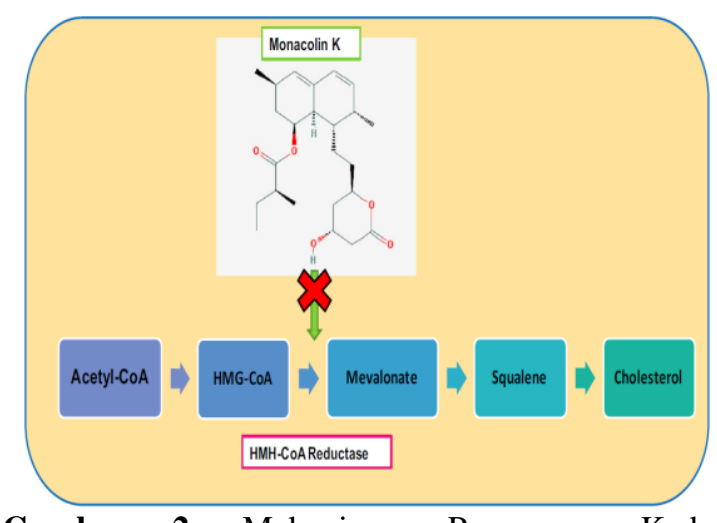

Gambar 2. Mekanisme Penurunan Kadar Kolesterol oleh Angkak (Sumber: Patel, 2016) (39).

Angkak dikenal dengan kemampuannya dalam menurunkan kadar kolesterol. Penurunan kadar kolesterol tersebut bekerja dalam mekanisme dimana senyawa monakolin $\mathrm{K}$ atau lovastatin dalam angkak menginhibisi kerja enzim HMG-KoA reduktase untuk menghasilkan kolesterol, yaitu pada proses pengubahan HMG -KoA menjadi mevalonat (Gambar 2). Pemberian angkak terbukti mampu menurunkan kadar total kolesterol, kadar trigliserida, dan kadar LDL, serta meningkatkan kadar HDL (7). Angkak dapat menjadi metode alternatif dalam menurunkan kadar kolesterol bagi pasien yang sensitif atau intoleran terhadap statin (38). Selain dapat menurunkan kadar kolesterol, angkak memiliki manfaat untuk meningkatkan metabolisme lemak, menurunkan tekanan darah, dan memiliki kemampuan anti-inflamasi, anti-diabetes, anti-kanker, dan properti ostogenik (39).

\section{Pembuatan Angkak}

Secara umum, angkak dibuat dari fermentasi kapang Monascus purpureus pada beras. Suspensi kultur Monascus purpureus diinokulasikan pada beras yang sudah direndam lalu disterilkan, kemudian diinkubasi selama 14 hari dan dikeringkan selama 2 hari (41). Pembuatan angkak juga dapat dimodifikasi dengan substrat yang 
berbeda, misalnya menggunakan biji durian (6), atau campuran ampas sagu dan tepung beras (42). Penggunaan jenis beras yang berbeda dalam pembuatan angkak dapat memberikan aktivitas antioksidan yang berbeda, yaitu $21,24 \%$ pada beras putih, $22,2 \%$ pada beras merah, dan $45,01 \%$ pada beras hitam (43). Pada penelitian lain pengukuran aktivitas antioksidan pada angkak beras putih menunjukkan hasil yang berbeda yaitu sebesar 45,61\% yang lebih tinggi daripada aktivitas antioksidan angkak jagung (44,05 \%) dan angkak gaplek (45,61\%) (44).

Substrat yang baik untuk menghasilkan produk angkak adalah bahan yang memiliki kadar amilosa tinggi dan amilopektin rendah (44). Monascus purpureus menghasilkan enzim protease dan amilase yang dapat memecah protein dan amilosa menjadi glukosa yang kemudian akan menghasilkan pigmen, sehingga beras putih merupakan substrat yang baik dalam pembuatan angkak (45). Perbedaan aktivitas antioksidan pada penggunaan jenis beras putih, merah, dan hitam disebabkan karena tingginya kadar antosianin pada beras hitam, sehingga aktivitas antioksidannya juga lebih tinggi (43). Kandungan vitamin B1 pada substrat juga menjadi salah satu faktor yang dapat mempengaruhi produksi metabolit sekunder, karena vitamin B1 merupakan koenzim yang mengkatalis pembetukan asetil KoA dalam pembentukan metabolit sekunder, serta seng sebagai senyawa yang mendukung pembentukan metabolit sekunder (46).

\section{Aplikasi Bekatul Beras Putih pada Cookies dan Roti}

Cookies dan roti tergolong sebagai produk bakery, yaitu produk olahan dari tepung dan lemak yang diolah dengan cara dipanggang. Penambahan bahan-bahan lain dalam produk bakery dapat dilakukan untuk meningkatkan nilai gizi maupun sensorinya, salah satunya adalah dengan penambahan bekatul beras putih. Fortifikasi tepung bekatul beras putih pada cookies dapat memberikan perubahan pada komposisi gizinya (Tabel 3). Substitusi bekatul beras putih pada roti juga terbukti meningkatkan komposisi gizi dan kadar antioksidan pada cookies (Tabel 4 dan Tabel 5).

Bekatul beras putih juga dapat ditambahkan pada cookies bebas gluten untuk meningkatkan kadar seratnya. Produk bebas gluten merupakan modifikasi produk pangan yang ditujukan untuk pasien celiac disease, dan umumnya memiliki kandungan serat yang rendah. Hal tersebut dapat diatasi dengan menambahkan bekatul beras putih yang merupakan sumber serat yang tinggi (2).

Tabel 3. Komposisi Gizi Cookies dengan Penambahan Bekatul Beras Putih

\begin{tabular}{cccccccc}
\hline $\begin{array}{c}\text { Kadar } \\
\text { Bekatul } \\
\text { Beras Putih } \\
\text { pada Cookies }\end{array}$ & $\begin{array}{c}\text { Kadar } \\
\text { Air }(\boldsymbol{\%})\end{array}$ & $\begin{array}{c}\text { Kadar } \\
\text { Abu } \\
(\boldsymbol{\%})\end{array}$ & $\begin{array}{c}\text { Kadar } \\
\text { Protein } \\
(\boldsymbol{\%})\end{array}$ & $\begin{array}{c}\text { Kadar } \\
\text { Lemak } \\
(\boldsymbol{\%})\end{array}$ & $\begin{array}{c}\text { Kadar } \\
\text { Serat } \\
(\boldsymbol{\%})\end{array}$ & $\begin{array}{c}\text { Kadar } \\
\text { Karbohidrat } \\
(\boldsymbol{\%})\end{array}$ & $\begin{array}{c}\text { Energi } \\
\text { (Kcal) }\end{array}$ \\
\hline $0 \%$ & 3,14 & 0,69 & 11,23 & 14,27 & 0,16 & 70,51 & 455,39 \\
$20 \%$ & 7,28 & 2,55 & 13,84 & 17,03 & 9,5 & 49,16 & 397,89 \\
\hline
\end{tabular}

Sumber: Mishra, 2017 (2) 
Tabel 4. Komposisi Gizi Roti dengan Substitusi Bekatul Beras Putih

\begin{tabular}{ccccc}
\hline $\begin{array}{c}\text { Perbandingan Tepung Gandum } \\
\text { dan Bekatul Beras Putih }\end{array}$ & $\begin{array}{c}\text { Kadar } \\
\text { Protein (\%) }\end{array}$ & $\begin{array}{c}\text { Kadar } \\
\text { Lemak (\%) }\end{array}$ & $\begin{array}{c}\text { Kadar } \\
\text { Abu (\%) }\end{array}$ & $\begin{array}{c}\text { Kadar Serat } \\
\text { Pangan (\%) }\end{array}$ \\
\hline $100: 0$ & 11,86 & 2,50 & 1,55 & 2,45 \\
\hline $70: 30$ & 13,07 & 6,17 & 3,96 & 6,42 \\
\hline
\end{tabular}

Sumber: Irakli dkk., 2015 (4)

Tabel 5. Kadar Antioksidan Roti dengan Substitusi Bekatul Beras Putih

\begin{tabular}{cccc}
\hline $\begin{array}{c}\text { Perbandingan Tepung Gandum } \\
\text { dan Bekatul Beras Putih }\end{array}$ & $\begin{array}{c}\text { Kadar } \\
\text { Vitamin E } \mathbf{( \% )}\end{array}$ & $\begin{array}{c}\text { Kadar Total } \\
\text { Fenolik (\%) }\end{array}$ & $\begin{array}{c}\text { Kadar Total } \\
\text { Flavonoid (\%) }\end{array}$ \\
\hline $100: 0$ & 14,6 & 45,8 & 34,8 \\
\hline $70: 30$ & 60,7 & 183,9 & 76,5 \\
\hline
\end{tabular}

Sumber: Irakli dkk., 2015 (4)

Cookies dan roti yang ditambahkan dengan bekatul beras putih memiliki perubahan pada parameter fisik. Cookies dengan fortifikasi tepung bekatul yang lebih tinggi memiliki spread ratio yang lebih kecil, sehingga lebar cookies juga menurun, yang disebabkan karena kandungan protein dan serat pada bekatul beras yang bersifat mengikat air, sehingga menahan pelebaran bentuk adonan (10). Penambahan bekatul pada roti memberikan penurunan pada volume, kekuatan gel, dan elastisitas, serta peningkatan pada kekerasan, yang disebabkan karena penyerapan air oleh serat yang terkandung dalam bekatul, sehingga pembentukan gluten menjadi terbatas dan mengurangi laju fermentasi dan pengembangan pada adonan (6). Selain pada kekerasan, penambahan bekatul beras putih juga dapat meningkatkan kekukuhan pada roti (4). Peningkatan kekukuhan dapat disebabkan karena penebalan dinding di sekitar gelembung udara pada remahan roti (47).

Selain dalam bentuk padat atau tepung, bekatul beras putih dapat dimanfaatkan minyaknya. Minyak bekatul beras putih mengandung sejumlah senyawa fungsional, diantaranya: sterol, tokoferol, tokotrienol, $\gamma$-orizanol, dan $\beta$-sitorterol (3). Minyak bekatul beras putih dapat digunakan dalam produk bakery dan memiliki potensi sebagai alternatif lemak terhidrogenasi. Minyak bekatul beras putih dalam bentuk spread telah digunakan dalam pembuatan kue, menghasilkan produk kue yang rendah lemak jenuh dan lemak trans, serta menunjukkan peningkatan dalam penilaian sensori (47).

\section{Aplikasi Angkak pada Cookies dan Roti}

Cookies dan roti dapat ditambahkan dengan zat pewarna untuk meningkatkan penilaian sensorinya. Angkak telah dimanfaatkan sebagai pewarna merah alami pada berbagai macam produk pangan. Penambahan angkak dapat memberikan warna merah gelap pada produk sosis hati sapi, yang juga berfungsi sebagai penguat rasa (48). Aplikasi angkak sebagai pewarna dan penguat rasa daging juga dapat diterapkan pada produk kornet daging ayam, yang juga mampu memperbaiki nilai cooking loss dan meningkatkan rendemennya, yang kemudian meningkatkan daya ikat air (49). Angkak dapat ditambahkan dalam bentuk tepung pada mie kering waluh, yang memberikan warna kemerahan yang disukai panelis sekaligus meningkatkan kadar protein dan aktivitas antioksidannya (50). Penambahan angkak pada produk terasi udang tidak 
memberikan perbedaan nyata dalam penilaian warna oleh panelis, namun angkak dapat bekerja sebagai anti bakteri dan anti kapang (5).

Cookies dan roti juga telah diolah dengan penambahan angkak sebelumnya. Penambahan angkak biji durian pada roti yang berhasil memberi corak warna merah yang disukai oleh panelis (6). Penambahan angkak pada produk cookies telah dilakukan sebelumnya, dan menunjukkan perubahan warna menjadi kemerahan yang disukai oleh panelis pada penambahan sebanyak 2,4 g (51). Penambahan angkak dalam jumlah yang sedikit tidak akan memberikan perubahan nyata terhadap parameter fisik cookies dan roti, termasuk kadar air dan aktivitas air karena angkak tidak memiliki kemampuan pengikatan komponen air (49). Belum banyak penelitian yang menunjukkan tentang pengaruh angkak secara spesifik terhadap produk cookies dan roti, sehingga masih terdapat peluang terhadap peningkatan parameter lain, termasuk kadar antioksidan, protein, lovastatin dan efek penurunan kolesterol.

Cookies dan roti merupakan produk yang diolah dengan suhu tinggi, sehingga berpotensi dalam mendegradasi senyawa bioaktif pada angkak. Kadar monakolin $\mathrm{K}$ dapat berkurang pada suhu yang lebih tinggi, yaitu pada suhu di atas $121{ }^{\circ} \mathrm{C}$ (52). Penambahan angkak sebanyak $2 \%$ dalam pembuatan garatteok (kue beras khas Korea) melalui proses perebusan pada suhu $100{ }^{\circ} \mathrm{C}$ dan pengukusan memiliki kadar lovastatin sebesar 19,20 ppm, sementara pada bubuk angkak memiliki kadar lovastatin sebesar 23,59 ppm (53).

Penggunaan angkak dalam berbagai produk cookies dan roti diikuti oleh kekhawatiran mengenai produksi senyawa citrinin pada angkak. Citrinin merupakan senyawa yang bersifat hepato-nephorotoxic yang dapat dihasilkan selama pertumbuhan sejumlah strain Monascus (8). Hingga saat ini, belum ada regulasi yang mengatur mengenai produksi angkak pasaran, penggunaannya di negara-negara Eropa dan Amerika Serikat pun masih dibatasi, karena angkak masih dianggap sebagai obat (38). Citrinin dapat dikonsumsi pada kadar di bawah $200 \mathrm{mg} / \mathrm{g}$, dan angkak yang dapat diperoleh di pasaran memiliki kadar citrinin pada kisaran 41-62 $\mu \mathrm{g} / \mathrm{g}$ (54). Sejauh yang telah diketahui, tidak ada kasus masalah kesehatan yang ditimbulkan oleh konsumsi angkak, sehingga pigmen Monascus dapat digunakan pada dosis normal sebagai pewarna makanan yang aman dikonsumsi (40).

Pemanasan angkak dalam campuran air pada suhu $130{ }^{\circ} \mathrm{C}$ selama 20 menit terbukti mampu mengurangi konsentrasi citrinin pada angka 50\% (54). Citrinin dapat terdekomposisi menjadi citrinin $\mathrm{H} 2$ pada suhu $175^{\circ} \mathrm{C}$ pada kondisi kering dan di atas $100{ }^{\circ} \mathrm{C}$ pada kondisi basah (55). Penelitian lain menunjukkan bahwa sementara citrinin H2 memiliki sifat toksik yang lebih lemah daripada citrinin, pemanasan angkak dengan air pada suhu $140{ }^{\circ} \mathrm{C}$ dapat menimbulkan toksisitas yang lebih tinggi karena dihasilkan senyawa citrinin $\mathrm{H} 1$ sebagai senyawa dimer (56). Pemanasan basah terhadap citrinin harus dilakukan pada kondisi yang tepat untuk mencegah terjadi peningkatan pada sifat toksik, yaitu idealnya pada suhu $100{ }^{\circ} \mathrm{C}$ selama 20 menit (57).

\section{SIMPULAN}

Bekatul beras putih dan angkak dapat ditambahkan pada cookies dan roti untuk meningkatkan beberapa parameter kualitasnya. Bekatul beras putih dapat diaplikasikan sebagai bahan penambah 
kadar lemak, serat, mineral, antioksidan, dan protein pada cookies dan roti, serta dapat merubah profil tekstur berdasarkan konsentrasi yang ditambahkan. Minyak bekatul juga memiliki potensi untuk menggantikan lemak terhidrogenasi pada cookies dan roti. Angkak dapat ditambahkan sebagai pewarna pada cookies dan roti, yang juga memiliki potensi manfaat lain, yaitu: meningkatkan kadar protein dan aktivitas antioksidan dalam cookies dan roti, serta menurunkan kadar kolesterol dalam darah. Terdapat sejumlah kekhawatiran mengenai produksi senyawa toksin oleh Monascus purpureus pada angkak, namun penggunaan dalam dosis yang wajar tidak akan menimbulkan masalah kesehatan yang serius, serta dapat dilakukan beberapa upaya untuk meminimalisir kadar citrinin pada angkak.

\section{UCAPAN TERIMA KASIH}

Penulis mengucapkan terima kasih kepada Fakultas Teknobiologi Universitas Atma Jaya Yogyakarta yang telah mendukung penulis dalam menyelesaikan naskah ini.

\section{KONFLIK KEPENTINGAN}

Penulis tidak memiliki konflik kepentingan dengan pihak manapun.

\section{REFERENSI}

1. Naim HJN. Pemanfaatan Bekatul sebagai Media Alternatif untuk Pertumbuhan Aspergillus sp. Media Anal Kesehat. 2016;VII(2):1-6.

2. Mishra N. Utilization of waste defatted rice bran in formulation of functional cookies and its effect on physiochemical characteristic of cookies. Int J Adv Sci Res [Internet]. 2017;2(5):64-8. Available from: http://www.allsciencejournal.com/ar chives/2017/vol2/issue5/2-5-25
3. Gul K, Yousuf B, Singh AK, Singh P, Wani AA. Rice bran: Nutritional values and its emerging potential for development of functional food-A review. Bioact Carbohydrates Diet Fibre [Internet]. 2015;6(1):24-30. Available from: https://www.sciencedirect.com/scie nce/article/pii/S2212619815300024

4. Irakli M, Katsantonis D, Kleisiaris F. Evaluation of quality attributes, nutraceutical components and antioxidant potential of wheat bread substituted with rice bran. J Cereal Sci [Internet]. 2015;65:74-80. Available from: http://europepmc.org/abstract/AGR/ IND605426479

5. Indriati N, Andayani F. Pemanfaatan Angkak Sebagai Pewarna Alami Pada Terasi Udang. J Pascapanen dan Bioteknol Kelaut dan Perikan [Internet]. 2012 Jun 14;7(1):11. Available from: http://www.bbp4b.litbang.kkp.go.id/ jurnaljpbkp/index.php/jpbkp/article/view/ 65

6. Trisnawati CY, Srianta I, Nugerahani I, Marsono Y. Incorporating Monascus-fermented durian seeds and rice bran into bread: study on the bread physicochemical and sensory properties. Food Res. 2018 Nov 7;3:280-4.

7. Wahyuningrum I, Zubaidah E. Pengaruh Angkak dengan Penambahan Bekatul Terhadap Penurunan Profil Lipid Tikus Wistar Jantan Hiperkolesterolemia. J Pangan dan Agroindustri. 2016;4(1):127-36.

8. Timotius K. Produksi pigmen angkak oleh Monascus. J Teknol dan 
Ind Pangan. 2004;15(1):79-86.

9. Žilić S, Kocadağlı T, Vančetović J, Gökmen V. Effects of baking conditions and dough formulations on phenolic compound stability, antioxidant capacity and color of cookies made from anthocyanin-rich corn flour. LWT - Food Sci Technol [Internet]. 2016 Jan;65:597-603. Available from: https://linkinghub.elsevier.com/retri eve/pii/S0023643815301511

10. Javaria S. Formulation and quality evaluation of aglutenics biscuits supplimented with rice bran for coeliac patients. Pure Appl Biol [Internet]. 2017 Dec 10;6(4). Available from: http://www.thepab.org/files/2017/D ecember-2017/PAB-MS-

1702040.pdf

11. Fuller S, Beck E, Salman H, Tapsell L. New Horizons for the Study of Dietary Fiber and Health: A Review. Plant Foods Hum Nutr. 2016 Mar;71(1):1-12.

12. Astawan Andi Early MF. Potensi Dedak dan Bekatul Beras Sebagai Ingredient Pangan dan Produk Pangan Fungsional. J PANGAN [Internet]. 2010; (Vol 19, No 1 (2010): PANGAN):14-21. Available from: http://www.jurnalpangan.com/index .php/pangan/article/view/104

13. Park H-Y, Lee K-W, Choi H-D. Rice bran constituents: immunomodulatory and therapeutic activities. Food Funct. 2017 Mar;8(3):935-43.

14. Anderson JW, Baird P, Davis RHJ, Ferreri S, Knudtson M, Koraym A, et al. Health benefits of dietary fiber. Nutr Rev. 2009 Apr;67(4):188-205.
15. Issara U, Rawdkuen S. Rice bran: A potential of main ingredient in healthy beverage. Int Food Res J. 2016 Dec 1;23:2306-18.

16. Rosniyana A, Hashifah MA, Norin $\mathrm{S}$. The physico-chemical properties and nutritional composition of rice bran produced at different milling degrees of rice (. In 2007.

17. Kurniati Y, Budijanto S, Nuraida L, Nur F, Dewi A, 085730953088 T:

Peningkatan Senyawa Fenolik Bekatul dengan SSF (Solid State Fermentation) sebagai Pencegah Kanker Enhancement of Phenolic Compounds of Rice Bran with SSF (Solid State Fermentation) for Preventing Cancer. Iptek Tanam Pangan [Internet]. 2017;12(2):97104. Available from: http://ejurnal.litbang.pertanian.go.id /index.php/ippan/article/view/8175

18. Nugrahawati T. Kajian Karakteristik Mie Kering dengan Substitusi Bekatul. Universitas Sebelas Maret; 2011.

19. Laokuldilok $\mathrm{T}$, Shoemaker CF, Jongkaewwattana S, Tulyathan V. Antioxidants and antioxidant activity of several pigmented rice brans. J Agric Food Chem. 2011 Jan;59(1):193-9.

20. Hartati S, Marsono Y, Suparmo S, Santoso U. Komposisi Kimia Serta Aktivitas Antioksidan Ekstrak Hidrofilik Bekatul Beberapa Varietas Padi. J Agritech [Internet]. 2015 May 4;35(01):35. Available from:

https://jurnal.ugm.ac.id/agritech/arti cle/view/9417

21. Oliveira MDS, Feddern V, Kupski L, Cipolatti EP, Badiale-Furlong E, de Souza-Soares LA. Changes in lipid, 
fatty acids and phospholipids composition of whole rice bran after solid-state fungal fermentation. Bioresour Technol. 2011 Sep;102(17):8335-8.

22. Jolfaie NR, Rouhani MH, Surkan PJ, Siassi F, Azadbakht L. Rice Bran Oil Decreases Total and LDL Cholesterol in Humans: A Systematic Review and MetaAnalysis of Randomized Controlled Clinical Trials. Horm Metab Res = Horm und Stoffwechselforsch = Horm Metab. 2016 Jul;48(7):41726.

23. Orthoefer F. Rice Bran Oil. In: Shahidi F, editor. Bailey's Industrial Oil and Fat Products. Seventh. John Wiley \& Sons, Ltd; 2020.

24. Irakli M, Lazaridou A, Biliaderis CG. Comparative Evaluation of the Nutritional, Antinutritional, Functional, and Bioactivity Attributes of Rice Bran Stabilized by Different Heat Treatments. Vol. 10, Foods . 2021.

25. Khan SH, Butt M, Anjum F, Jamil A. Antinutritional Appraisal and Protein Extraction from Differently Stabilized Rice Bran. Pakistan J Nutr. 2009 Aug 1;8.

26. Bhaskaragoud G, Rajath S, Mahendra VP, Kumar GS, Gopala Krishna AG, Kumar GS. Hypolipidemic mechanism of oryzanol components- ferulic acid and phytosterols. Biochem Biophys Res Commun. 2016 Jul;476(2):829.

27. Perez-Ternero C, Alvarez de Sotomayor M, Herrera MD. Contribution of ferulic acid, $\gamma-$ oryzanol and tocotrienols to the cardiometabolic protective effects of rice bran. J Funct Foods [Internet]. 2017;32:58-71. Available from: https://www.sciencedirect.com/scie nce/article/pii/S1756464617300865

28. Yilmaz N, Tuncel NB, Kocabiyık H. Infrared stabilization of rice bran and its effects on $\gamma$-oryzanol content, tocopherols and fatty acid composition. J Sci Food Agric. 2014 Jun;94(8):1568-76.

29. Shafi M, Baba WN, Masoodi FA, Bazaz R. Wheat-water chestnut flour blends: effect of baking on antioxidant properties of cookies. J Food Sci Technol [Internet]. 2016/12/17. 2016 Dec;53(12):427888. Available from: https://pubmed.ncbi.nlm.nih.gov/28 115768

30. Echavarría Vélez AP, Pagán J, Ibarz A. Melanoidins Formed by Maillard Reaction in Food and Their Biological Activity. Food Eng Rev. 2012 Dec 1;4:203-23.

31. Nooshkam M, Varidi M, Bashash M. The Maillard reaction products as food-born antioxidant and antibrowning agents in model and real food systems. Food Chem [Internet]. 2019;275:644-60. Available from: http://europepmc.org/abstract/MED/ 30724245

32. Jan U, Gani A, Ahmad M, Shah U, Baba WN, Masoodi FA, et al. Characterization of cookies made from wheat flour blended with buckwheat flour and effect on antioxidant properties. J Food Sci Technol. 2015 Oct;52(10):6334-44.

33. Bhosale S, Vijayalakshmi D. Processing and Nutritional Composition of Rice Bran. Curr Res Nutr Food Sci J [Internet]. 2015 Apr 
30;3(1):74-80. Available from: http://www.foodandnutritionjournal. org/volume3number1/processingand-nutritional-composition-of-ricebran/

34. Oliveira MG de C, Bassinello PZ, Lobo VL da S, Rinaldi MM. Stability and microbiological quality of rice bran subjected to different heat treatments. Food Sci Technol [Internet]. 2012 Aug 23;32(4):72533. Available from: http://www.scielo.br/scielo.php?scri $\mathrm{pt}=$ sci_arttext\&pid=S010120612012000400014\&lng=en\&tlng $=$ en

35. Patil S, Kar A, Mohapatra D. Stabilization of Rice Bran using Microwave: Process Optimization and Storage Studies. Food Bioprod Process. 2016 May 1;99.

36. Kim S-M, Chung H-J, Lim S-T. Effect of various heat treatments on rancidity and some bioactive compounds of rice bran. J Cereal Sci [Internet]. 2014 Jul;60(1):243-8. Available from: https://linkinghub.elsevier.com/retri eve/pii/S0733521014000782

37. Loypimai P, Moonggarm A, Chottanom P. Effects of ohmic heating on lipase activity, bioactive compounds and antioxidant activity of rice bran. Aust J Basic Appl Sci. 2009;3(4):3642-52.

38. Nguyen T, Karl M, Santini A. Red Yeast Rice. Foods. 2017 Mar 1;6:19.

39. Patel S. Functional food red yeast rice (RYR) for metabolic syndrome amelioration: a review on pros and cons. World J Microbiol Biotechnol. 2016 May;32(5):87.

40. Mapari SAS, Thrane U, Meyer AS. Fungal polyketide azaphilone pigments as future natural food colorants? Trends Biotechnol. 2010 Jun;28(6):300-7.

41. Wahid AR, Damayanti A, Wardani AK. Uji Aktivitas Antikolesterol Hasil Fermentasi Angkak pada Tikus Galur Sprague Dawley. J Insa Farm Indones [Internet]. 2019 Dec 28;2(2):250-60. Available from: http://jiis.akfar-

isfibjm.ac.id/index.php?journal=JIF I\&page $=$ article \&op=view $\&$ path $\% 5$ B\%5D=296

42. Asben A, Kasim A. Studi Lama Fermentasi dan Tingkat Kadar Air dalam Produksi Pigmen Angkak pada Substrat Ampas Sagu-Tepung Beras Menggunakan Monascus purpureus. Food Nutr Sci [Internet]. 2015;(September):185-91.

Available from: http://www.scirp.org/journal/doi.asp $\mathrm{x}$ ?DOI=10.4236/fns.2011.28115

43. Wanti S, Andriani MA., Herriyadi N. Pengaruh Berbagai Jenis Beras Terhadap Aktivitas Antimikrobia Pada Angkak Oleh Monascus purpureus. Biiofarmasi. 2015;13(1):1-5.

44. Wiyoto H, Andriani MA, Parnanto NHR. Study of antioxidant activity and anti-cholesterol content on red yeast rice with substrates variation (rice, corn and dried cassava). Biofarmasi J Nat Prod Biochem [Internet]. 2011 Aug 17;9(2):38-44. Available from: https://smujo.id/jnpb/article/view/19 05

45. Danuri H. Optimizing Angkak Pigments and Lovastatin Production By Monascus purpureus. Hayati J Biosci [Internet]. 2008 Jun;15(2):61-6. Available from: 
https://linkinghub.elsevier.com/retri eve/pii/S1978301916302698

46. Zubaidah E, Dewi A. Effect Addition of Rice Bran on Fermentation Process to Increasing Lovastatin and Intensity of Red Pigment Angkak. Adv J Food Sci Technol. 2014 Jan 10;6:56-9.

47. Shaik R, Kuna A, Azam M, Tilathoo R, Kanuri M, Samala G. Effect of rice bran oil spread on the physical, sensory and fatty acid profile of cake. J Food Sci Technol [Internet]. 2017/05/16. 2017 Jun;54(7):212634. Available from: https://pubmed.ncbi.nlm.nih.gov/28 720970

48. Atma Y, Trilogi U, Trilogi K. Studi Penggunaan Angkak sebagai Pewarna Alami dalam Pengolahan Sosis Daging Sapi. J Teknol. 2015;7(2):2015.

49. Afdhal M, Lukman H, Indriyani I. Potensi Angkak sebagai Pewarna Alami Terhadap Karakteristik Kornet Daging Ayam. J Ilm Ilmu Terap Univ Jambi [Internet]. 2017 Dec 14;1(2):154-61. Available from: $\quad$ https://onlinejournal.unja.ac.id/index.php/JIITUJ/ article/view/4277

50. Anam C, Handayani S. Mi Kering Waluh (Cucurbita moschata) dengan Antioksidan dan Pewarna Alami. Caraka Tani J Sustain Agric. 2010;25(1):72.

51. Murdopo. Kadar Serat Pangan dan Sifat Organoleptik Cookies dengan Penambahan Tepung Biji Kluwih (Antocarpus communis) dan Angkak Sebagai Pewarna Alami. Universitas Muhammadiyah Surakarta; 2014.

52. Ou H-P, Wang C-CR, Lai L-S. Thermal degradation kinetics analysis of monacolin $\mathrm{K}$ in Monascus-fermented products. LWT - Food Sci Technol [Internet]. 2009 Jan;42(1):292-6. Available from:

https://linkinghub.elsevier.com/retri eve/pii/S0023643808001412

53. Asben A, Murtius WS, Rifka A. Antioxidant Activity and Lovastatin Content in Garaetteok (Korean Rice Cake) with Angkak Powder as Food Colouring. IOP Conf Ser Earth Environ Sci [Internet]. 2020 Jun 23;515:012048. Available from: https://iopscience.iop.org/article/10. 1088/1755-1315/515/1/012048

54. Triana E, Yulinery T. Uji toksisitas citrinin yang dihasilkan oleh angkak hasil fermentasi berbagai isolat Monascus purpureus terhadap larva Artemia salina Leach. In: Prosiding Seminar Nasional Masyarakat Biodiversitas Indonesia. 2015. p. 283-8.

55. Doughari J. The Occurrence, Properties and Significance of Citrinin Mycotoxin. J Plant Pathol Microbiol [Internet]. 2015;6(11). Available from: https://www.omicsonline.org/openaccess/the-occurrence-propertiesand-significance-of-citrininmycotoxin-2157-74711000321.php?aid=65382

56. Wang W, Liao Y, Zhang B, Gao M, Ke W, Li F, et al. Citrinin Monomer and Dimer Derivatives with Antibacterial and Cytotoxic Activities Isolated from the Deep Sea-Derived Fungus Penicillium citrinum NLG-S01-P1. Mar Drugs [Internet]. 2019 Jan 10;17(1):46. Available from: https://pubmed.ncbi.nlm.nih.gov/30 
634700

57. Silva LJG, Pereira AMPT, Pena A, Lino CM. Citrinin in foods and supplements: A review of occurrence and analytical methodologies. Foods. 2021;10(1). 